\title{
PRESENTATION OF THYROGLOSSAL CYST IN CHILDREN
}

\author{
SNF RUMI ${ }^{1}$, SM AHMAD ${ }^{2}$, S RAHMAN $^{3}$, AH TABLU ${ }^{4}$
}

\begin{abstract}
Background: Thyroglossal duct cyst a developmental anomaly present as a congenital cervical masses of neck in children.

Objectives: To observe its deferent presentation and evaluate among the children.

Materials and methods: This observational cross section study conducted among patients of eighteen years of age present with thyroglossal duct cyst between 2007 to 2012 in the department of ENT and HeadNeck surgery, Dhaka Medical College Hospital, Dhaka. All patients were operated by Sistrunk operation under (excision of total cyst and removal median portion hyoid bone) under general anesthesia. All specimens were histo-pathologically confirmed.
\end{abstract}

Results: Among 24 children with thyroglossal cyst, 15 boys and 9 girls with male female ratio 1.67:1, age ranged from 4 years to 18 years (mean 9.46 std \pm 4.27 ). Male (mean7.53 \pm 4.01 years) child are younger than female (mean12.67 \pm 2.39 years) child. $66.67 \%$ male children were below 10 years of age and $88.89 \%$ female children were over 10 years of age. According to the presentation site $17(70.83 \%)$ cases were juxtra hyoid, $4(16.67 \%)$ were suprahyoid and $3(12.50 \%)$ were infrahyoid. $23(95.83 \%)$ were present as midline swelling, only $1(4.17 \%)$ was present as left lateral infrahyoid swelling. 4(16.67\%) patient were attended as thyroglossal fistulae with

1. Dr. Shaikh Nurul Fattah Rumi, Associate Professor, Department of ENT \& Head-Neck Surgery, Dhaka Medical College, Dhaka.

2. Dr. Shaikh Muniruddin Ahmad, Junior Consultant (ENT), Upazila Health Complex, Kapasia, Gazipur.

3. Dr. Shahnaz Rahman, Senior Medical Officer, Department of Gynae \& Obstetric, BIRDEM Hospital 2, Segunbagicha, Dhaka.

4. Prof. Dr. Abdul Hanif Tablu, Department of Pediatric Surgery, Dhaka Medical College, Dhaka.

Correspondence to: Dr. Shaikh Nurul Fattah Rumi, Associate Professor, Department of ENT \& Head-Neck Surgery, Dhaka Medical College, Dhaka. E-mail: rumi17dr@gmail.com history of intervention. $4(16.67 \%)$ patient were developed recurrence followed by surgical resection within two years.

Conclusion: Thyroglossal duct cyst present as an asymptomatic midline neck mass around the hyoid region in children. Complete resection along with median portion hyoid bone prevents recurrence.

Key words: Thyroglossal duct cyst, developmental neck mass, midline neck swelling.

\section{Introduction}

A Thyroglossal duct cyst is a developmental anomaly, which is cystic dilatation of the persistence epithelial remnants of the thyroglossal duct tract. Thyroglossal duct cyst (TDC) is the most common benign developmental lesion of the neck, constitute $70 \%$ of all the congenital cervical masses ${ }^{1}$. They comprise approximately one-third of congenital neck masses in children ${ }^{2}$, second most common of all childhood cervical neck masses ${ }^{3}$.

It develops from the persistence of thyroglossal tract during the development of the hyoid bone and subsequent embryogenesis and descent of the thyroid gland and failure of complete obliteration of the duct ${ }^{4}$.

During the fourth week of development the thyroid enlage arises as an invigination of endoderm in the floor of pharynx between the tuberculum impar and posterior third of the tongue. During embryogenesis thyroid primordium migrate caudally with the descent of great vessels. It passes either anterior, posterior or through the hyoid bone in mid line of the neck ${ }^{5}$. During its migration the gland remains connected to the tongue by a narrow canal, the thyroglossal tract. This tract normally atrophies and disappears between fifth to tenth weeks, though the caudal end often remains as pyramidal lobe among one third of people. No 
natural internal opening of thyroglossal duct has been demonstrated at the level of foramen cecum as the tongue and foramen cecum forms after the complete descent of the thyroglossal duct. Rarely a tract could be found at the level of foramen cecum.

Portions of this epithelial tract and remnants of thyroid tissue may persist, due to failure of the complete obliteration of the tract. It may develop anywhere along the course of the duct remnant, from the base of the tongue to the suprasternal region. The commonest site of this is just above or just below the hyoid bone ${ }^{6}$.

The Thyroglossal duct cyst may be formed as a result of undergoing cystic degeneration of epithelial remnants of the persistent tract due to recurrent throat inflammation and or a blocked thyroglossal duct expands as a result the of retention of secretion ${ }^{7}$ as the continuous mucous production from the glands found in the duct ${ }^{8}$.

Cysts located near the foramen caecum are lined by pseduo stratified ciliated columnar with some squamous epithelium, whereas cysts located near the thyroid gland are lined by cells similar to thyroidal acinar epithelium ${ }^{9}$. Functional thyroid tissue within the TDC has been described and more than half contain normal thyroid tissue in their walls.$^{10}$

Any part of the tract can persist causing a sinus, fistulae or cyst. Formation of the cyst is likely. Most fistulae and sinuses are acquired following rupture or incision of infected thyroglossal cyst. Occasionally, a sinus tract is present in the midline without a visible cyst ${ }^{11}$.

It may be found in patients of any age ${ }^{12}$ with equal male-to-female incidence ${ }^{13}$. The Thyroglossal duct cyst (TDC) is a developmental anomaly, but it does not appear as a congenital lesion ${ }^{14}$. Up to $50 \%$ thyroglossal cysts are not diagnosed until adult life. The tract can lie dormant for years or even decades until some kind of stimulus leads to cystic dilation. It is more common in children ${ }^{15}$. Typically it appears in a parson over the 5 years of life ${ }^{16} .60 \%$ of lesions are diagnosed before the age of 20 with over $30 \%$ presenting before ten years of age. ${ }^{17},{ }^{18}$

It is mostly asymptomatic. Some patients will have neck or throat pain or dysphagia due to the size of this mass or due to infection.

Diagnosis is usually clinical, history and physical examination are required for the correct diagnosis. Upwards movement during swallowing or on protrusion of the tongue (because of its attachment to the tongue via the tract of thyroid descent) is its cardinal sign.

Ultrasonography will help to confirm the diagnosis and identify the presence of normal thyroid gland in neck ${ }^{19}$. Commonly this cyst could contain thyroid tissue. Thyroid scans with I ${ }^{131}$ is needed when normal thyroid tissue is not found or all patients with suprahyoid masses ${ }^{20}$. Rarely this could be the only functioning thyroid gland tissue.

Thyroglossal cysts are treated surgically. Although generally benign the cyst will be removed if the patient exhibits difficulty in breathing or swallowing, or if the cyst is infected. Even if these symptoms are not present the cyst may be removed to eliminate the chance of infection or development of a carcinoma ${ }^{21}$, or for cosmetic reasons if there is unsightly protrusion from the neck.

The surgical resection involves excision of the cyst along with its tract and concomitant removal of the central portion (midsection) of the hyoid bone (to ensure complete removal of the tract) for avoid recurrence. It is called Sistrunk procedure. Wenglowski who suggested that along with the body of hyoid bone a core of tissue between the hyoid bone and the tongue should also be removed to reduce the incidence of recurrence.

The purpose of this study was to review the cases and describe the clinical presentations and site distribution of the thyroglossal cyst in our experience. Another aim is to ensure the absence of the recurrences by correct removal of the cyst.

\section{Materials and Methods}

This cross sectional observational descriptive study was conducted at the Department of ENT and HeadNeck Surgery, Dhaka Medical College Hospital. Dhaka.from January 2007 to December 2012. A total of twenty four patients of ages below 18 years and both sexes who were operated during the study duration were included in the study. Patients above 18 years were excluded from the study. A detailed history and thorough physical examination was conducted. Ultrasound studies were done in all cases to confirm the cystic nature of the lesion and the presence of normal thyroid gland at its normal site. FNAC was also done preoperatively to exclude other pathology and to study the type of pathology histopathology also done. Thyroid scan was done to confirm the lesion are the only thyroid tissue or not and normal thyroid gland present or not. 
A semi structured proforma was made to collect all the necessary information of the patient available. Management was mainly surgical and Sistrunk operation was done in all cases. Cyst was removed through a horizontal incision made at the inferior border of the mass along with body of the anomalies a core of suprahyoid muscles was removed. This was done to prevent any recurrence. Follow up was done at one, two, four week and six months interval for any complications and recurrence.

\section{Results}

Among 24 children (aged before 18 years) of thyroglossal cyst, 15 boys and 9 girls with male female ratio 1.67:1, age ranged from 4 years to 18 years (mean $9.46 \mathrm{std} \pm 4.27$ ). Male (mean7.53 \pm 4.01 years) child are younger than female (mean12.67 \pm 2.39 years) child. $66.67 \%$ male children were below 10 years of age and $88.89 \%$ female children were over 10 years of age.

According to the presentation site $17(70.83 \%)$ cases were juxtra hyoid, $4(16.67 \%)$ were suprahyoid and 3 (12.50\%) were infrahyoid. 23 (95.83\%) were present as midline swelling, only $1(4.17 \%)$ was present as left lateral infrahyoid swelling. 4(16.67\%) patient were attended as thyroglossal fistulae with history of intervention. $4(16.67 \%)$ patient were developed recurrence followed by surgical resection within two years. Histopathologically one cyst was reported as papillary carcinoma other were reported benign. In two patient $(8.34 \%)$ it was the only thyroid tissue of the neck.

Table-I

Age and Sex distribution of the children with Thyroglossal cyst $(n=24)$

\begin{tabular}{lcccccc}
\hline Age & Male & $\%$ & Female & $\%$ & Total & $\%$ \\
\hline <5yrs & 3 & 20.0 & 0 & 0.00 & 3 & 12.5 \\
5-10yrs & 7 & 46.6 & 1 & 11.1 & 8 & 33.3 \\
>10yrs & 5 & 33.3 & 8 & 88.9 & 13 & 54.2 \\
Total & 15 & 100.0 & 9 & 100.0 & 24 & 100.0 \\
\hline
\end{tabular}

Chi-square $=7.138$ with 2 degrees of freedom. $(P=$ 0.028)

\section{Table-II}

Age of the children in relation to their sex with Thyroglossal cyst $(n=24)$

\begin{tabular}{lrcc}
\hline Sex & Number \% & Mean & Std \\
\hline Male & $15(62.5 \%)$ & 7.53 & 4.02 \\
Female & $9(37.5 \%)$ & 12.67 & 2.40 \\
Total & $24(100 \%)$ & 9.46 & 4.27 \\
\hline
\end{tabular}

$t=-3.464$ with 22 degrees of freedom. $(P=0.002)$

Table-III

Presentation of the Thyroglossal Duct Cyst $(n=24)$

\begin{tabular}{lcc}
\hline Presentation & No & $\%$ \\
\hline Neck mass (midline) & 23 & 95.83 \\
Discharging sinus & 1 & 4.17 \\
Globus & 6 & 25.00 \\
Dysphagia & 2 & 8.33 \\
Sore throat & 2 & 8.33 \\
Pain & 3 & 12.50 \\
Hoarseness & 1 & 4.17 \\
Others & 1 & 4.17 \\
\hline Total & 24 & 100 \\
\hline
\end{tabular}

Most of the patient (95.83\%) was presented as an asymptomatic midline neck mass which gradually increasing in size. Six $(25 \%)$ children had globus like sensation and three $(12.5 \%)$ children had pain due to infection. Only $8.33 \%$ children had the complaint of dysphagia or sore throat.

Table-VI

Sonographic features of the Thyroglossal Duct Cyst $(n=24)$

\begin{tabular}{lcc}
\hline Sonographic Features & No & $\%$ \\
\hline Echogenicity & & \\
Anechoic & 8 & 33.33 \\
Hypoechoic (homogenous) & 8 & 33.33 \\
Hyperechoic (complex) & 4 & 16.67 \\
Hyperechoic pseudosolid & 3 & 12.50 \\
Hyperechoic Solid & 1 & 4.17 \\
Posterior enhancement & & \\
Well defined & 21 & 87.50 \\
Subtle & 3 & 12.50 \\
Cyst Wall & & \\
Thin & 15 & 62.50 \\
Thick & 5 & 20.83 \\
Imperceptible & 4 & 16.67 \\
Total & 24 & 100.0 \\
Size (mm) & Mean & SD \\
Range 10-30mm & $19.04 \mathrm{~mm}$ & $4.66 \mathrm{~mm}$ \\
\hline
\end{tabular}


Table-V

Presentation of the Thyroglossal Duct Cyst according to their sites $(n=24)$

\begin{tabular}{|c|c|c|c|c|c|c|c|c|c|}
\hline \multicolumn{2}{|c|}{ Character } & \multirow{2}{*}{$\begin{array}{c}\text { Supra hyoid } \\
4\end{array}$} & \multirow{2}{*}{$\begin{array}{c}\% \\
100\end{array}$} & \multirow{2}{*}{$\begin{array}{c}\text { Juxtrahyoid } \\
17\end{array}$} & \multirow{2}{*}{$\begin{array}{c}\% \\
100\end{array}$} & \multirow{2}{*}{$\frac{\text { Infrahyoid }}{2}$} & \multirow{2}{*}{$\begin{array}{c}\% \\
66.7\end{array}$} & \multirow{2}{*}{$\begin{array}{c}\text { Total } \\
23\end{array}$} & \multirow{2}{*}{$\begin{array}{c}\% \\
95.8\end{array}$} \\
\hline Side & Midline & & & & & & & & \\
\hline & Left & 0 & 0 & 0 & 0.0 & 1 & 33.3 & 1 & 4.2 \\
\hline & Right & 0 & 0 & 0 & 0.0 & 0 & 0.0 & 0 & 0.0 \\
\hline \multirow[t]{3}{*}{ Age } & $<5 y r$ & 2 & 50 & 1 & 5.9 & 0 & 0.0 & 3 & 12.5 \\
\hline & $5-10 y r$ & 2 & 50 & 5 & 29.4 & 1 & 33.3 & 8 & 33.3 \\
\hline & $>10 y r$ & 0 & 0 & 11 & 64.7 & 2 & 66.7 & 13 & 54.2 \\
\hline \multirow[t]{2}{*}{ Sex } & Male & 2 & 50 & 12 & 70.6 & 1 & 33.3 & 15 & 62.5 \\
\hline & Female & 2 & 50 & 5 & 29.4 & 2 & 66.7 & 9 & 37.5 \\
\hline \multicolumn{2}{|c|}{ Habitat } & 0 & & 0.0 & & 0.00 & 0 & 0.00 & \\
\hline \multicolumn{2}{|l|}{ Urban } & 3 & 75 & 7 & 41.2 & 1 & 33.3 & 11 & 45.8 \\
\hline \multicolumn{2}{|c|}{ Rural } & 1 & 25 & 10 & 58.8 & 2 & 66.7 & 13 & 54.2 \\
\hline \multicolumn{10}{|c|}{ Socioeconomic } \\
\hline & Poor & 1 & 25 & 9 & 52.9 & 2 & 66.7 & 12 & 50.0 \\
\hline & Middle & 2 & 50 & 5 & 29.4 & 1 & 33.3 & 8 & 33.3 \\
\hline & Upper & 1 & 25 & 3 & 17.6 & 0 & 0.0 & 4 & 16.67 \\
\hline & Fistulae/ & 0 & 0 & 2 & 11.8 & 1 & 33.3 & 3 & 12.50 \\
\hline \multicolumn{10}{|c|}{ Recurrance } \\
\hline & $<6$ month & 0 & 0 & 1 & 5.9 & 0 & 0.0 & 1 & 4.17 \\
\hline & 6-12 month & 1 & 25 & 0 & 0.0 & 0 & 0.0 & 1 & 4.17 \\
\hline & $12-24$ month & 0 & 0 & 1 & 5.9 & 0 & 0.0 & 1 & 4.17 \\
\hline & $>24$ month & 0 & 0 & 0 & 0.0 & 1 & 33.3 & 1 & 4.17 \\
\hline Total & 4 & 100 & 17 & 100 & 3 & 100 & 24 & 100 & \\
\hline
\end{tabular}

Table-VI

Presentation of the Thyroglossal Duct Cyst according to the age of the children( $n=24)$

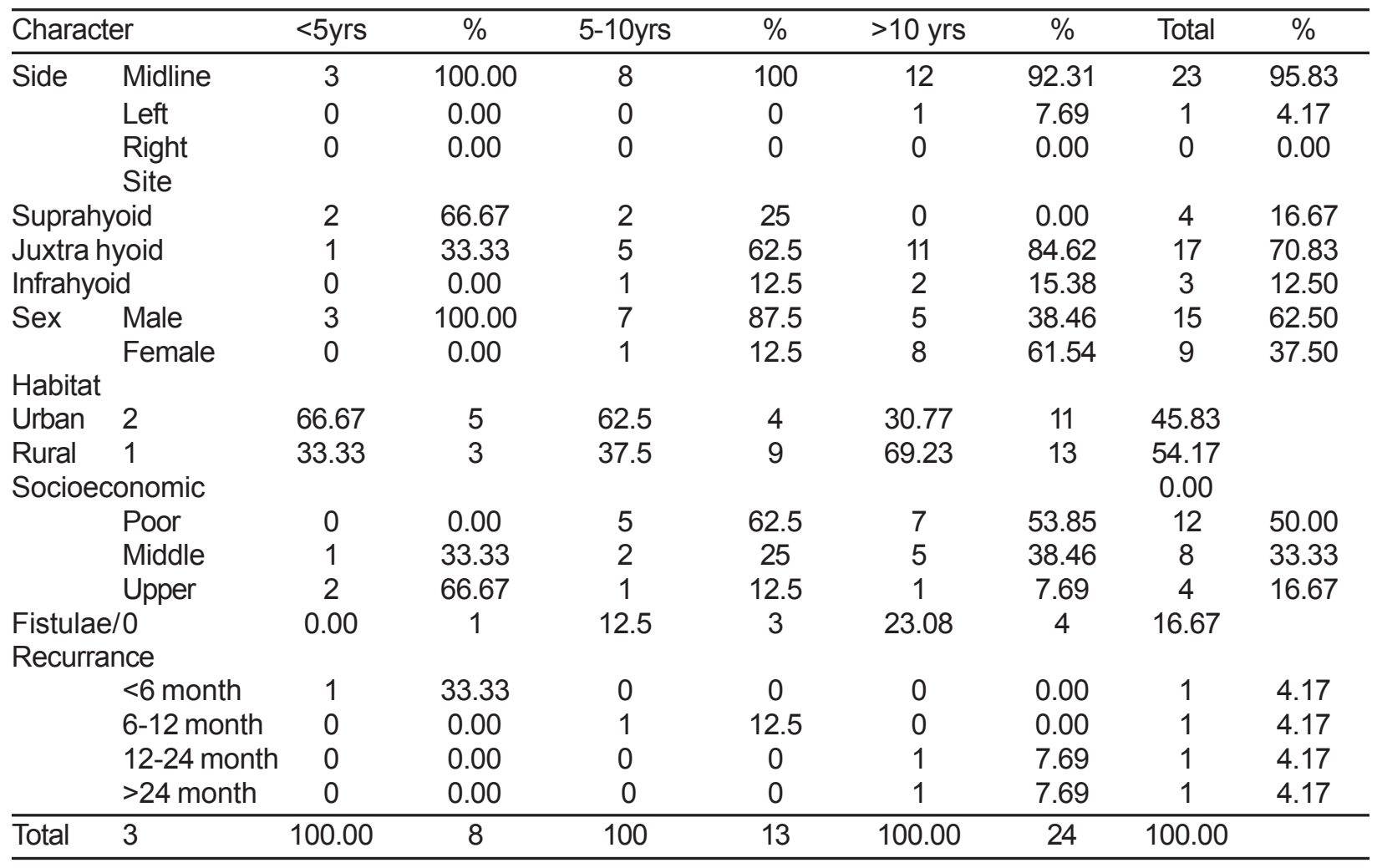




\section{Discussion}

The thyroglossal duct cyst is a well recognized developmental abnormality most often seen as congenital asymptomatic mass of the neck region $7 \%$ of the population. While TDCs are most often diagnosed in the pediatric age group, a substantial minority of patients with TDCs are over 20 years of age at the time of diagnosis 22 .

It typically presents as a mobile, painless mass in the anterior midline of the neck, usually in close proximity to the hyoid bone. Less often, TDCs may present with signs and symptoms of secondary infection, or with evidence of a fistula. The standard surgical approach to TDC, encompassing removal of the mid-portion of the hyoid bone in continuity with the TDC and excision of a core of tissue between the hyoid bone and the foramen cecum of tongue, dates back to the late 19th and early 20th centuries and is often referred to as Sistrunk's operation. Malignancy is rarely encountered in TDCs; when such rare tumors do develop (in the order of $1 \%$ or so of patients with TDCs), they usually take the form of either papillary carcinoma of thyroid origin, or squamous carcinoma.

The presence of these duct remnants may lead to abnormal phonation and epithelial carcinomas. Therefore, correlation of the rate of thyroglossal duct remnants in a population together with the related clinical symptoms can lead to an early diagnosis and better treatment chances for these problems.

Thyroglossal duct cyst is a developmental disorder of the thyroid where cystic degeneration developed in the persistent thyroglossal duct due to interruption of developing hyoid bone during its descends. It represent the most common congenital anomaly of the neck constitute $70 \%$ of all the congenital cervical masses ${ }^{23}$ and accounting for $2-4 \%$ of all neck masses.

Thyroglossal cysts (TGCs) represent the most common congenital anomaly of the neck, 1 accounting for $2-4 \%$ of all neck masses.

\section{Sex:}

It is found equally in both girls and boys. ${ }^{24}$. Males are more commonly affected than female seen in some series $^{25}$. In this series male is more than female (M:F= 1.6:1).

Age:

In a study conducted by Brousseau $\mathrm{V} J$ et al14 bimodal distribution for age at presentation of thyroglossal cyst but this finding was not present in our study ${ }^{26}$.

Regarding age of presentation there was a significant difference between the male and female $(p=<0.05)$. Female are presented later age (mean 12.67士 2.40years)than male (mean 7.53 \pm 4.01 years).

The mean age at presentation in other study other studies were 13.18 years.

On the other hand males were affected more frequently compared to females in our study, ratio of 3.1: 1 , which is in agreement with other studies ${ }^{27}$.

\section{Site:}

The lesion usually presents as an asymptomatic painless swelling in the anterior midline or paramidline of the neck ${ }^{28}$, extending from the base of the tongue (foramen cecum) to the sternal manubrium ${ }^{29} .{ }^{30} .90 \%$ of thyrogossal duct cysts are found in mid line, 10\% are to one side of the neck, with $95 \%$ percent on the left and $5 \%$ percent on the right ${ }^{31}$. Three forth of the lesions are usually found below the hyoid bone. The cyst may become infected presenting as a painful tense mass with overlying erthymatous skin. This may result in sinus formation due to spontaneous rupture or a surgical drainage attempt ${ }^{32}$.

It is frequently presented as midline neck mass that moves with swallowing and protrusion of the tongue.

They may be found anywhere from base of tongue to manubrium ${ }^{33}$. In this study $70.83 \%$ cases were in juxtrahyoid (around the hyoid region). In other study Asmatullah et al in pakistan $75.6 \%$ were in infrahyoid region ${ }^{34}$. Deaver MJ et al also found most cases inferior to the hyoid bone $65 \%{ }^{35}$. Chon SH et al have reported TDC from the mediastinum ${ }^{36}$. Lin ST et al studied patients with left sided TDCs ${ }^{37}$ but only one case in this study had left sided neck swelling.

\section{Presentation}

Most of the patient (95.83\%) was presented as an asymptomatic midline neck mass which gradually increasing in size. Six (25\%) children had globus like sensation and three $(12.5 \%)$ children had pain due to infection. Only $8.33 \%$ children had the complaint of dysphagia or sore throat.

Presenting features may be sore throat, pain, dysphagia, hoarseness, and globus ${ }^{38}$. However, we did not see any case of pain or hoarseness. They may present as infected cyst, discharging sinus, true fistula ${ }^{39}$ or intra thyroid cyst ${ }^{40}$. 
Less commonly reported manifestations in the literature include acute airway obstruction, misdiagnosed as laryngomalacia in children ${ }^{41}$.

Though the diagnosis is mainly clinical, ultrasonography is of great help. We subjected all

cases to ultrasound study and our finding of with homogenously hypoechoic picture $(78.1 \%)$ have similar $(78.1 \%)$ with the study of Asmatullah et al , were different from the study done by Ahuja AT et al, who reported $28 \%$ each for anechoic, pseudosolid and heterogeneous picture ${ }^{42}$.

The presence of a solid mass along the thyroglossal duct cyst should raise the suspicion of ectopic thyroid tissue, as it is estimated that $35-70 \%$ may contain thyroid tissue in their wall ${ }^{43}$. Rarely, a thyroglossal cyst may contain the only functioning thyroid tissue in the body.

Although only $10 \%$ of ectopic thyroid is found in the neck, it may represent the only thyroid tissue in $75 \%$ of patients ${ }^{44}$. In this series $4(16.67 \%)$ of the cases were found only thyroid tissue in this remnant.

There is a malignant potential of the dysgenetic thyroid tissue located in a thyroglossal duct cyst; carcinoma develops more frequently in ectopic thyroid tissue than in normal thyroid glands ${ }^{45}$. Carcinoma arising in a thyroglossal duct remnant was first reported in 1925 by Ashurst and White. Most of the patients were in the third through the sixth decades of life. Cancer occurs more frequently in females than in males ${ }^{46}$.

Additional cases of Hürthle cell adenoma and very rarly squamous cell carcinoma were found ${ }^{47}$.

Approximately $85-92 \%$ of all thyroglossal duct cyst carcinomas are papillary carcinoma ${ }^{48}$. Although they are characterized by relatively non-aggressive behavior and rare lymphatic spread ${ }^{49}$, the possibility of occult malignancy should be evaluated in such cases.

The presence of calcification in a TGDC on imaging studies suggests papillary carcinoma [because these areas of calcification are psammoma bodies, a histologic hallmark of papillary carcinoma]. About $1 \%$ of TDC are found ultimately to harbor thyroid carcinoma which was first reported by Ucherman in 1915.

One of the cases $(4.17 \%)$ found papillary carcinoma other were reported benign ${ }^{50}$.
Most TGDCs are asymptomatic but could be secondarily infected in an upper respiratory tract infection ${ }^{51}$. Allard (1982) reported that inflammation was the most often mentioned initiating stimulus. Inflammation may lead to a rapid increase in size, cellulitis and even abscess formation ${ }^{52}$. Fistulization onto skin, as seen in two of our patients, occurs in approximately one third of patients ${ }^{53}$. Fistulas may form as a result of spontaneous discharge following inflammation of a cyst, or after surgical intervention, or rarely as congenital fistulas.

\section{Sonograph}

The size of the cyst ranged from $10-30 \mathrm{~mm}$ in diameter (mean 19.04 SD \pm 4.66 ).

The typical sonographic description of a TDC has been that of an anechoic, well-circumscribed cyst with increased through-transmission ${ }^{54}$. However, earlier studies in children have shown that most are not simple cysts but instead are either homogeneous or heterogeneous complex hypoechoic lesions ${ }^{55}$.

The pseudosolid appearance of cystic lesions may be due to the proteinaceous content of the fluid, thought to be secreted by the epithelial lining of the cyst. Posterior enhancement suggests the nature of a true cystic ${ }^{56}$.

The pseudosolid appearance of cystic lesions has been described previously for other congenital cystic lesions in the neck, such as branchial cleft cysts and dermoid cysts. The echogenic appearance

is due to the presence of cellular material, cholesterol crystals, and keratin within the cyst ${ }^{57}$.

In this series $33.3 \%$ cyst are sonographically anechoic and hypoechoic. One had a hyperechoic solid component. This result is consistent with the study by Ahuja AT et al ${ }^{58}$, where anechogenecity and hypoechogenicity was $28 \%$ and $18 \%$ respectively. Heteroechogenicity and Psuedosolid was $28 \%$. Posterior enhancement was well defined in $87.50 \%$ cases.

All the TDCs in this study were well defined. In $62.5 \%$ of the lesions, the walls were thin; $20.83 \%$ were thickwalled; and in the remaining $16.6 \%$, the walls were imperceptible. Study of Ahuja AT et al showed $88 \%$ have posterior enhancement and $50 \%$ had well defined thin walled. 


\section{Conclusion}

Thyroglossal duct cyst present as midline neck swelling around the hyoid region. Sometimes it present as globus like presentation and dysphagia. When present with pain it is due to infection.

\section{References}

1. Allard RHB. The thyroglossal cyst. Head Neck Surg 1982; 5: 134- 146.

2. Torsiglieri AJ: Pediatric neck masses: guidelines for evaluation. Int J Pediatr Otorhinolaryngol 1988; 16:199.

3. Lee D. Rowe, Congenital Anomalies of the Head and Neck ,Ballenger's Otorhinolaryngology edts, Cf 46- 1076-77

4. Sistrunk WE. Technique of removal of cysts and sinuses of the thyroglossal duct. Surg Gynecol Obstet 1928; 46: 109.

5. Langman J. Medical embryology. 4th ed. Baltimore: Williams \& Wilkins, 1981:280-1

6. Maran AGD, Benign diseases of the neck. Laryngology and head-neck surgery edt John Hibbert. Scott Brown's Otolaryngology, edt Kerr AG, $6^{\text {th }}$ ed. Vol-5: 16/357-359.

7. Soucy P, Penning J. The clinical relevance of certain observations on the histology of the thyroglossal tract. J Pedia Surg 1984; 19: 506509.

8. Okstad S, Mair MB, Sundsfjord JA, et al. Ectopic thyroid tissue in the head and neck. J Otolaryngol 1986;15:152-155

9. Saeed M. Management of thyroglossal sinus.Professional Med J Mar 2011;18(1):93-96.

10. Deaver MJ, Silman EF, Ltfipour S. Infected thyroglossal duct cyst. West J Emerg Med 2009;10:205

11. Clark $P$ : Benign neck disease: infections and swellings the neck. Scott-Brown's Otorhinolaryngology, Head and Neck Surgery 7th edition Lead editor: Michael Gleeson Vol:2 Chapter 140: 14: 1779

12. Santiago W, Rybak LP, Bass RM. Thyroglossal duct cyst of the tongue. JOtolaryngol 1985; 14 : 261-264

13. D, Neampu, S. Cotulbea,A.H.Marin,S. Lupescu1,N. Balica,A. Ruja,A. Thyroglossal duct cyst and fistula. Mag. Journal of Experimental Medical \& Surgical Research Year XVII .3/2010 Pag. $210-214$

14. Ward GE, Hendrick JW, Chambers RG. Thyroglossal tract abnormalities - Cysts and fistulas. Surg Gyne Obstetrics 1949; 89: 727734.

15. Madana J,Yolmo D, Saxena SK, Gopalkrishnan $\mathrm{S}$. True thyroglossal fistula. Laryngoscope 10 2009;119:2345-7.

16. Brewis C, Mahadevan M, Bailey C M, Drake D P. Investigation and treatment of thyroglossal cysts. J R. Soc Med 2000; 93:18-21.

17. Perez MA, Bento BL, Martnez BMA, Conde CJ, Miguel MC. An intra thyroid thyroglossal duct cyst. Eur J Peadiatr Surg 2005; 15:428-30.

18. Asmatullah, Thyroglossal duct cyst: descriptive study of 41 cases. JPMI 2010. Vol-24 No. 03: 231-233.

19. Dedivitis RA, Camargo DL, Peixoto GL, Weissman L, Guimaraes AV. Thyroglossal duct: A review of 55 cases. J Am Coll Surg 2002; 194:274-277

20. McNicoll MP, Hawkins DB, England K, Penny R, Maceri DR (1988). "Papillary carcinoma arising in a thyroglossal duct cyst". OtolaryngologyHead and Neck Surgery 99 (1): 50-54.

21. Mondin V, Ferlito A, Muzzi E, Silver CE, Fagan JJ, Devaney KO, Rinaldo A. Thyroglossal duct cyst: personal experience and literature review. Auris Nasus Larynx. 2008 Mar;35(1):11-25. Epub 2007 Aug 27.

22. PETER CLARKE:Chapter 140 Benign neck disease: infections and swellings 14: the neck . Scott-Brown's Otorhinolaryngology, Head and Neck Surgery; 7th edition Lead editor: Michael Gleeson Vol:2 1779

23. Hirshoren N, Neuman T, Udassin R, Elidan J, Weinberger JM. The imperative of operation: review of 160 thyroglossal tract remnant operations. Otolaryngol Head Neck Surg 2009;140:338-42.

24. Brousseau VJ, Solares CA, Xu M, Krakovitz $P$,Thyroglossal duct cysts presentation and management in children versus adults. Int $\mathrm{J}$ Pediatr Otorhinolaryngol. 2003 Dec;67(12): 128590. 
25. Swaid and Al-Ammar. Management of Thyroglossal Duct Cyst. The Open Otorhinolaryngology Journal, 2008, Volume 2 -28

26. Asma'a Abdulrahman Al-Ekrish, Omar Saad AlJonaidel,Hezekiah A. Mosadomi, Thyroglossal duct cyst. A clinicopathological study of five cases Saudi Dental Journal, Vol. 15, No. 2, May - August 2003;108-111

27. Ehsan Khadivi,, Hossein Payedar Ardekani,Double thyroglossal duct cyst derived from a single tract: a rare presentation. The Iranian Journal of Otorhinolaryngology Vol. 22, No.60, Summer-2010.

28. Pediatric Surgery Schwartz's Principles of Surgery, Ninth Edition McGraw-Hill 2010 Chapter 39.

29. Lin ST, Tseng FY, Hsu CJ, Yeh TH, Chen YS. Thyroglossal duct cyst: a comparison between chi ldren and adul t . Am J Otolaryngol 2008;29:837.

30. Deaver MJ, Silman EF, Ltfipour S. Infected thyroglossal duct cyst. West J Emerg Med 2009;10:205.

31. Pueyo C, Royo Y, Maldonado J, Skrabski R, Gris $F$, Landeyro J, et al. Double cervical cyst derived from a single thyroglossal duct tract. J Pediatr Surg 2008;43:748-50.

32. Hsieh YY, Hsueh S, Hsueh C, Pathological analysis of congenital cervical cysts in children 20 years experience at Chang Gung Memorial Hospital. Chang Gung Med J 2003 Feb 26(2): 107-13

33. Asmatullah, Thyroglossal duct cyst: descriptive study of 41 cases. JPMI 2010. Vol-24 No. 03: 231-233.

34. Deaver MJ, Silman EF, Ltfipour S. Infected thyroglossal duct cyst. West J Emerg Med 2009;10:205.

35. Chon SH ,Shinn SH, Lee CB, Tae K, Lee YS, Jang SH, et al. Thyroglossal duct cyst within the medistinum: an extremely unusual location. J Thorac Cardiovasc Surg 2007;133:1671-2.

36. Lin ST, Tseng FY, Hsu CJ, Yeh TH, Chen YS. Thyroglossal duct cyst: a comparison between chi Idren and adul t . Am J Otolaryngol 2008;29: 83-7.
37. Ali LS, Ahmed Y, Al-ammar. Management of thyroglossal duct cyst. Open Otolaryngol J 2008;2:26-8.

38. Madana J,Yolmo D, Saxena SK, Gopalkrishnan S. True thyroglossal fistula. Laryngoscope 10 2009;119:2345-7.

39. Perez MA, Bento BL, Martnez BMA, Conde CJ, Miguel MC. An intra thyroid thyroglossal duct cyst. Eur J Peadiatr Surg 2005;15:428-30.

40. Fu J, X ue X, Chen L, e t al. L ingual thyroglossal duct cyst in newborns: previously misdiagnosed as laryngomalacia . Int J Pediatr Otorhinolaryngol $2008 ; 72: 327-32$

41. Ahuja AT, King AD, King W, Metreweli $C$. Thyroglossal Duct Cysts : Sonographic Appearances in Adults. Am J Neuroradiology 1999;20:579-82.

42. McHenry CR, Danish R, Murphy T, Marty JJ. Atypical thyroglos-sal duct cyst: a rare cause for a solitary cold thyroid nodule in childhood. Am Surg 1993;59:223-228.

43. Lee D. Rowe,Congenital Anomalies of the Head and Neck ,Ballenger's Otorhinolaryngologyedts, Cf 46- 1076-77

44. Hofmann V, K ösling $S$, Thanh PN, e t al. P apillary thyroid carcinoma in a thyroglossal duct cyst: primary tumor or metastasis? . HNO 2009 ; $57: 719-24$.

45. Ishay A, Ellmalah I, Luboshitzky R. Papillary carcinoma in a thyroglossal duct cyst. Isr Med Assoc J 2008;10:312-3.

46. Bardales RH, Shurland MJ, Korourian $\mathrm{S}$, et al. Cytologic findings in thyroglossal duct carcinoma. Am J Clin Pathol 1996;106:615-9

47. Weiss SD, Orlich CC. Primary papillary carcinoma of a thyro-glossal duct cyst: report of a case and literature review. Br J Surg 1991;78: 87-89

48. Kazemi M, Assadi M, Kazemi AA, Ghazvini LA. Primary pap-illary carcinoma in a thyroglossal duct cyst. Hell J Nucl Med 2006;9:39-40.

49. Jamal S, Mamoon N, Luqman M. Thyroglossal duct carcinoma. J Coll Physician Surg Pak Surg 2009;140:338-42. 2002;12:755-9.

50. Pelausa EO, Forte V. Sistrunk revisited: A 10year review of revision thyroglossal duct surgery 
at Toronto's Hospital for Sick Children. J Otolaryngol 1989; 18: 325- 333.

51. Cumberworth VL, Bradley PJ. Atypical thyroglossal duct cyst. J Laryngol Otol 1989; 103: 700-703.

52. Massoud TF, Schnetler JFC. Case report: Taste of success in thyroglossal fistulography. Clin Radiol 1992; 45: 281- 283.

53. Friedman AP, Haller JO, Goodman JD, Nagar H. Sonographic evaluation of non-inflammatory neck masses in children. Radiology 1983;147:693-697

54. Kraus R, Han BK, Babcock DS, Oestreich AE. Sonography of neck masses in children. AJR Am J Roentgenol 1986;146: 609-613

55. Sherman NH, Rosenberg HK, Heyman S, Templeton J. Ultrasound evaluation of neck masses in children. J Ultrasound Med 1985;4:127-134

56. Wadsworth DT, Siegel MJ. Thyroglossal duct cysts: variability of sonographic findings. AJR Am J Roentgenol 1994;163:1475-1477

57. Baatenburg de Jong RJ, Rongen RJ, Lameris JS, Knegt $P$, Verwoerd CDA. Ultrasound characteristics of thyroglossal duct anomalies. ORL 1993;55:299-302

58. Reynolds JH, Wolinski AP. Sonographic appearance of branchial cysts. Clin Radiol 1993;2:109-110

59. Anil T. Ahuja, Ann D. King, Walter King, and Con Metreweli. Thyroglossal Duct Cysts: Sonographic Appearances in Adults AJNR Am J Neuroradiol April 1999. 20:579-582, 